\title{
Groundwater Consumption, Quality and Economics in a Higher Education Institution: A Water Sustainability Initiative
}

\author{
Cecilia A Geronimo ${ }^{1,{ }^{*}}$ and Audie L Geronimo ${ }^{2}$ \\ ${ }^{1}$ Civil Engineering Department, College of Engineering, Bulacan State University, City of Malolos, Bulacan, Philippines, \\ 3000. \\ 2 Mechanical Engineering Department, College of Engineering, Bulacan State University, City of Malolos, Bulacan, \\ Philippines, 3000.
}

Global Journal of Engineering and Technology Advances, 2021, 08(01), 072-083

Publication history: Received on 08 June 2021; revised on 13 July 2021; accepted on 15 July 2021

Article DOI: https://doi.org/10.30574/gjeta.2021.8.1.0103

\begin{abstract}
The demand for groundwater in a Higher Education Institution is very imperative since it's the only source of water, all were drawn from its deep wells and shallow wells. The land areas were all occupied by buildings and concrete roads, only two parks have spaces with soil. Thus, the groundwater consumption, quality, and economics of a Higher Education Institution were evaluated. The mixed methods of research were used, checklist, questionnaire, and secondary data from the different offices were made to gather data on the status of the groundwater consumption in terms of water supply facilities and fixtures, the microbiological and physicochemical properties of groundwater to monitor the water quality, the cost of the extracted and distributed groundwater for its economics, including the problems encountered by the stakeholders on water supply and the proposed groundwater sustainability management plan. The volume of groundwater consumption was computed based on the formulas in the Philippine Plumbing Code, the laboratory tests results were compared with the Philippine National Standard on Drinking Water, and the cost of water facilities and fixtures were taken from the office in charge of infrastructure development. The faculty members, non-teaching personnel, and students were interviewed about the problems encountered in the water supply, and based on the results of the study a Water Sustainability Management initial plan was proposed.
\end{abstract}

Keywords: Groundwater; Consumption; Water quality; Economics; Water sustainability

\section{Introduction}

Water is very important for human existence and all types of activities like the production of goods and provision of services, such as education, energy, transportation, manufacturing, and others. All living things, like humans, animals, and plants are very dependent on the availability of water sources. These water sources experience continuous changes due to various changes being done on it, like biological, chemical, and geological. The hydrologic cycle is continuously changing, before, the wet season occurs during June to October and the dry season from November to May, but this time as if there is no distinction on the wet and dry seasons, due to the changes in space utilization and very high demands on groundwater quantity and quality for different uses.

One of the seventeen Sustainable Development Goals is clean water and sanitation" which ensures the availability and sustainable management of water and sanitation in the world. The continuous changes and development manifest the continuous extraction of groundwater. Freshwater consumed every day by the people, plants, and animals is sourced out from the aquifers underneath the natural grade. The COVID 19 pandemic is a manifestation that clean water for drinking, cooking, washing our hands, bathing before entering our house is very essential to prevent infections. The

\footnotetext{
* Corresponding author: Cecilia A Geronimo

Civil Engineering Department, College of Engineering, Bulacan State University, City of Malolos, Bulacan, Philippines, 3000.
} 
challenge is the availability of water sustainable management plan in the world, in a developing country, specifically in urban cities where there is a big population composed of minimal percent of the middle class to rich population and a major percentage are poor or belonging to the lowest strata of socioeconomic level, these are the people living in slum areas, who cannot afford to buy clean and safe water. All institutions whether the government and private are needing water for the operation of their activities to accomplish and attain their objectives and goals.

The population of the Higher Education Institution is continuously increasing hence, there are many academic activities, construction of buildings is being implemented annually, and so as the renovation of existing structures, demands for groundwater extraction is becoming imperative.

The Higher Education Institution administration focuses on improving the physical facilities where the students, faculty members, and non-teaching personnel will be accommodated. Maintenance and management of buildings, classrooms, offices, laboratory rooms, shops, utility rooms, comfort rooms, and other rooms, should be made to provide improved and better services.

The three major utilities provided by the Higher Education Institution are water, power, and communication. Water is essential to perform laboratory experiments, in maintaining the cleanliness and sanitation of the buildings, food preparation and services, health and medical services, and other operational activities.

The Higher Education Institution stakeholders like the faculty members, non-teaching personnel, and students have inadequate knowledge of the value of water in everyday operations. Concern on water use, how groundwater is recharged, and the possible contamination of water may not be included in their priorities. Also, it is noticeable that buildings in the Higher Education Institution are mostly aging, hence, most of the water supply fixtures are old and there may be leaking pipes. Further, in most land areas infrastructure is constructed. The few available spaces with soil are the two parks and small quadrangle, and these may influence groundwater quality impairment and diminished water availability.

To assist the Higher Education Institution in meeting its vision and mission, the researchers thought of evaluating the groundwater consumption, determine the groundwater qualities or characteristics, policies to be drafted to minimize the cost of water production, and develop a plan to have sufficient groundwater supply.

There are water resource challenges that may be encountered by the administration to provide sufficient, clean, and safe water to its stakeholders.

This may be an initial research action plan to be used as a basis in a macro research portfolio that may provide science and engineering solutions for the Higher Education Institution to attain its goals and objectives, while also attempting to develop a new paradigm for efficient, innovative, and responsive water sustainability actions.

\section{Material and methods}

\subsection{Methods and techniques of the study}

This study used a mixed method of descriptive research. The study looked into the groundwater consumption, quality, and economics of a Higher Education Institution (HEI). The data gathered through the use of the said method may be the basis for future plans to sustain water supply sourced out from the ground. The researchers prepared a questionnaire to be accomplished by respondents whose work pertains to water supply maintenance, professionals, faculty members, non-teaching personnel, and students. Aside from accomplishing the questionnaire, the respondents were interviewed about the problems they have encountered in using the water supply facilities and fixtures in the HEI. Validation of the data gathered was done through ocular observations by the researchers. The research collaborator was once designated as Director of the Building and Ground Management Office now called Facilities Management and Maintenance Office and a registered Mechanical Engineer, as such aware of the problems and solutions in terms of water supply.

\subsection{Population and Sample of the study}

The respondents of the study are the maintenance or utility workers in the Facilities Management and Maintenance Office, professionals in the Project Management Office, faculty members, non-teaching personnel, and students. The maintenance or utility workers were requested to accomplish the questionnaire where the status of the groundwater consumption of the HEI may be identified in terms of the number of deep wells; capacity of water stored in all tanks; 
the number of water closets, urinals, slop sinks, and lavatories; the number of showers/bathrooms in the hostel/ dormitory; and the average volume of groundwater extracted every day. Also, they were interviewed including the faculty members, non-teaching personnel, professionals, and students about the different problems encountered and its corresponding solutions to provide potable and clean water supply for the University stakeholders.

\subsection{Research Instruments}

The research utilized questionnaire, interviews, and secondary data from the Department of Science and Technology (DOST) Analytical Testing Laboratory for the microbiological and physicochemical properties of the extracted groundwater of the deep wells and shallow wells in the HEI; the population of the faculty members and non-teaching personnel from the Human Resource Management Office while the student population from the Office of the Registrar; groundwater economic value in terms of electricity cost of groundwater extraction (extractive value) from the Accounting office; and cost of pipes, motors, pumps in the extraction and distribution of groundwater from the Supply Office aside from those included in the construction and installation of water supply fixtures in the buildings provided by the Project Management Office.

\subsection{Data Gathering Procedure}

The letter of request for the respondents to be involved and the answer was included in the questionnaire of this study. Letter of request and accomplished request slips from the different offices were used to gather all the documents needed in the study. A letter of request for the interviewees was handed personally and beforehand a call or message was made to conduct the face-to-face and online interview.

\subsection{Data Processing and Statistical Tools used in the study}

The primary data gathered from the research questionnaire and secondary data from the offices were retrieved. The responses were tabulated and encoded. A descriptive measure such as frequency count was utilized and a formula from the book titled Plumbing Design and Estimate by Max B. Fajardo Jr. second edition was used. In the book of Max B. Fajardo Jr, the National Plumbing Code prepared by its committee conducted various tests on various plumbing fixtures to determine the amount of water each fixture discharges in one-minute intervals through their outlet orifices. They were able to establish the basis of the so "Unit Fixture" which represents one cubic foot or 30 liters of Fixture Unit Values

\begin{tabular}{|l|c|}
\hline \multicolumn{1}{|c|}{ Kind of Fixture } & Fixture Unit \\
\hline Water Closet & 6 \\
\hline Urinal & 5 \\
\hline Lavatory & 1 \\
\hline Floor drain & 1 \\
\hline Slop sink & 3 \\
\hline Shower bath & 2 \\
\hline Bidet & 1 \\
\hline
\end{tabular}

The fixture unit value will be multiplied by the number of water supply fixtures to determine the maximum water discharge for plumbing fixtures in terms of units. The maximum demand of water supply is equal to the total fixture units in the plumbing system wherein one unit is approximately valued at 8 gallons of water discharge per minute interval. If the HEI buildings' water supply fixtures are operating from seven o'clock in the morning until seven o'clock in the evening, approximately equal to seven hundred twenty (720) minutes. Also, from the same book, there was this assumption of the probability of simultaneous use of fixtures, it was suggested to consider this figure.

\begin{tabular}{|c|c|}
\hline Number of fixtures & Percentage of simultaneous use \\
\hline 1 to 5 & 50 to 100 \\
\hline 6 to 50 & 25 to 50 \\
\hline 51 or more & 10 to 25 \\
\hline
\end{tabular}

Therefore, to determine the water consumed per day in terms of the water supply fixtures, the equation is as follows: 
The volume of water consumed= number of fixtures $\mathrm{x}$ unit value $\mathrm{x}$ demand per fixture $\mathrm{x}$ percentage of simultaneous use $\mathrm{x}$ operation minutes of HEI

The volume of water consumed per day has a unit of gallons.

\section{Results and discussion}

\subsection{Status of groundwater consumption in the Higher Education Institution}

\subsubsection{Deep wells and Shallow wells in the Higher Education Institution (HEI)}

The plumbers, utility workers, and foreman of the Facility Maintenance and Management Office indicated in the questionnaire checklist the number of deep wells and shallow wells existing in the HEI. Fourteen deep wells are being used to extract groundwater and supply water to the midrise buildings and 11 shallow wells for watering the plants in the parks and comfortable rooms of one-storey buildings. The deep well was described as having more than ten pipes length with six-meter length each and the diameter of the pipe varies from four to six inches while the shallow well was less than ten pipes of six-meter length each and the diameter of the pipe varies from two to three inches. All of the pipes are drilled whether deep wells or shallow wells and connected to a submersible pump or pressurized pump to increase the pressure of water horizontally from one place to another or vertically from the ground level to the elevated tower water tanks and gravity water tanks.

\subsubsection{Tank Capacity}

In the HEI, there are three elevated tower water tanks with varying capacities of two five thousand gallons each and one forty thousand gallons. There are eight gravity water tanks installed in the highest elevation level of the buildings with a capacity of four-five hundred gallons each and two with a capacity of one thousand gallons each. These three elevated tower water tanks are continuously supplying the water needs of midrise buildings near the location of the elevated tower water tanks. The elevated tower tank with forty thousand gallons is supplying water to most buildings of the HEI, there were distribution pipes laid along with the road networks, and the elevated gravity water tanks were supplied with water from the elevated tower water tank of forty thousand gallons. Pressure tanks with booster pumps or vertical transfer pumps per building were connected to distribution pipes of the three elevated tower water tanks.

\subsubsection{Water supply fixtures per Building}

Table 1 presents the water supply fixtures existing per building. The water supply fixtures existing in the buildings are the water closet with the attached bidet, urinal, slop sink, and lavatory. The eighteen buildings have a grand total number of two hundred ninety-seven (297) water closets with bidets while there are one hundred forty-four (144) urinals, seventy-four (74) slop sinks, and two hundred twenty-three (223) lavatories. All of the water supply fixtures were installed during the construction of the buildings and some were replaced due to non-functionality as part of the maintenance.

\subsubsection{Water Supply Fixtures in the Hostel/Dormitory}

The water supply fixtures for the Hostel/Dormitory were shown in table 2. Two buildings being utilized for the accommodation of the guests, faculty, non-teaching personnel, and students in the HEI. The water supply fixtures consisted of the water closet with attached bidet, urinal, lavatory, and shower head in the bathroom. The total water supply fixtures being used in the hostel/dormitory are seventy-four (74) water closets with bidets, four (4) urinals, seventy-five (75) lavatories, and sixty-eight (68) bathrooms with sixty-eight (68) showerheads.

\subsubsection{Population of Faculty members, Nonteaching personnel and Students}

In the HEI, the three major stakeholders are the faculty members, non-teaching personnel, and students. There are one thousand three hundred thirty [1330] faculty members, four hundred seventy-six [476] non-teaching personnel, and twenty-three thousand eight hundred fifty[23850] students with a total population of twenty-five thousand six hundred fifty-six $[25,656]$ using the extracted groundwater every day. 
Table 1 Total number of water supply fixtures per building

\begin{tabular}{|c|c|c|c|c|}
\hline $\begin{array}{c}\text { Building } \\
\text { Description }\end{array}$ & $\begin{array}{c}\text { Water } \\
\text { Closet/Bidet }\end{array}$ & Urinal & Slop Sink & lavatory \\
\hline$A$ & 21 & 6 & 5 & 19 \\
\hline B & 32 & 15 & 10 & 26 \\
\hline $\mathrm{C}$ & 30 & 8 & 8 & 24 \\
\hline $\mathrm{D}$ & 24 & 8 & 0 & 16 \\
\hline $\mathrm{E}$ & 32 & 12 & 3 & 3 \\
\hline $\mathrm{F}$ & 8 & 4 & 2 & 8 \\
\hline G & 4 & 2 & 2 & 4 \\
\hline $\mathrm{H}$ & 2 & 0 & 1 & 2 \\
\hline I & 2 & 0 & 1 & 2 \\
\hline $\mathrm{J}$ & 12 & 6 & 3 & 14 \\
\hline $\mathrm{K}$ & 24 & 16 & 8 & 20 \\
\hline $\mathrm{L}$ & 16 & 7 & 2 & 14 \\
\hline M & 41 & 21 & 15 & 18 \\
\hline $\mathrm{N}$ & 8 & 4 & 4 & 10 \\
\hline 0 & 8 & 4 & 2 & 8 \\
\hline $\mathrm{P}$ & 1 & 1 & 0 & 1 \\
\hline $\mathrm{Q}$ & 6 & 6 & 0 & 8 \\
\hline $\mathrm{R}$ & 26 & 24 & 8 & 26 \\
\hline Grand Total & 297 & 144 & 74 & 223 \\
\hline
\end{tabular}

Table 2 Total number of water supply fixtures for the dormitory

\begin{tabular}{|l|c|c|c|c|c|}
\hline $\begin{array}{c}\text { Building } \\
\text { Description }\end{array}$ & $\begin{array}{c}\text { Water } \\
\text { Closet/Bidet }\end{array}$ & Urinal & Lavatory & Shower Head & Bathroom \\
\hline $\mathrm{S}$ & 51 & 2 & 52 & 45 & 45 \\
\hline $\mathrm{T}$ & 23 & 0 & 23 & 23 & 23 \\
\hline Grand Total & 74 & 2 & 75 & 68 & 68 \\
\hline
\end{tabular}

\subsubsection{The average volume of extracted groundwater every day}

The average volume of groundwater consumed every day in all the midrise buildings as shown in table 1 was computed in terms of the grand total water supply fixtures, fixture units, water demand per minute, percentage of simultaneous use, and time of daily operation in the HEI. The total volume of groundwater consumed every day is 622,488 gallons broken down as follows: water closets flushed 342,144 gallons; urinals used 138,240 gallons; lavatories discharged 42,816 gallons; slop sinks used 42,264 gallons, and the bidets discharged 57,024 gallons.

On the other hand, the water average volume of groundwater consumed every day in the Hostel/dormitory as presented in table 2 was also computed in terms of the grand total water supply fixtures, fixture units, water demand per minute, percentage of simultaneous use, and time of daily operation in the HEI. The total volume of groundwater consumed every day is 40,656 gallons contributed from the different water supply fixtures in the Hostel/dormitory, to wit; water 
closets flushed 21,312 gallons; urinals used 2,400 gallons; lavatories discharged 3,600 gallons, showerheads discharged 6,528 gallons; bathroom floor drain discharged 3,264 gallons, and bidets used 3,552 gallons.

\subsection{Water Quality of the extracted groundwater in the HEI}

Table 3 Microbiological Test Results of Water from the different Water Tanks of the HEI for the year 2019

\begin{tabular}{|l|l|l|l|l|}
\hline \multirow{2}{*}{ Tank No. } & Coliform Count & \multirow{2}{*}{ EPN coli Count MPN } & \multicolumn{2}{|l|}{ PNSDW standard } \\
\cline { 3 - 5 } & & & Coliform count & E. coli Count \\
\hline Tank 1 & less than 1.1 & less than 1.1 & less than 1.1 & less than 1.1 \\
\hline Tank 2 & less than $1.1 / 23$ & less than $1.1 / 23$ & less than 1.1 & less than 1.1 \\
\hline Tank 3 & less than 1.1 & less than 1.1 & less than 1.1 & less than 1.1 \\
\hline Tank 4 & $23 /$ less than 1.1 & 23/less than 1.1 & less than 1.1 & less than 1.1 \\
\hline Tank 5 & $\begin{array}{l}\text { Less than } 1.1 / 23 / \\
\text { more than } 1600\end{array}$ & $\begin{array}{l}\text { Less than } 1.1 / 23 / \\
\text { more than } 1600\end{array}$ & less than 1.1 & less than 1.1 \\
\hline Tank 6 & $23 /$ less than 1.1 & $23 /$ less than 1.1 & less than 1.1 & less than 1.1 \\
\hline Tank 7 & 23 & 23 & less than 1.1 & less than 1.1 \\
\hline Tank 8 & less than 1.1 & less than 1.1 & less than 1.1 & less than 1.1 \\
\hline
\end{tabular}

Table 3 presents the Microbiological test results of the water in the eight water tanks, distributing water to the water supply fixtures of all buildings in the HEI. The laboratory technician mentioned that every quarter of the year, the DOST Analytical Testing Laboratory is getting samples from these water tanks to monitor its water quality. It can be gleaned from the table that the parameters tested are the Coliform Count and Fecal Coliform (E. coli) count in Most Probable Number (MPN), likewise, the Philippine National Standards for Drinking Water (PNSDW), Department of Health,2007 was used as a reference if the samples complied with the standards. As shown from the table, there were tanks that the values of the Coliform count and E. coli count varies from less than 1.1 to twenty-three and more than 1600 , water tanks $2,4,5,6,7 \& 8$ while water tanks 1 and 3 from the quarterly test were complying with the PNSDW standards of less than 1.1 MPN. The samples tested from water tanks $1 \& 3$ were consistently Negative for E. coli (Fecal Coliform) and showed less than 1.1 MPN per $100 \mathrm{ml}$ of the sample. The coliforms are absent in the sample and samples showed results that are within the standards set by PNSDW, therefore, suitable for drinking.

The physicochemical properties of the water sample from the water tanks in the HEI for the year 2019 were shown in Table 4. The physicochemical properties were in terms of $\mathrm{pH}$, total hardness, Calcium hardness, alkalinity, total dissolved solids, color, odor, and taste. The Philippine National Standards for Drinking Water have the following standard values per physicochemical properties: pH: 6.5-8.5; Total hardness: 300 ppm CaCO3; Calcium hardness: 300 ppm CaC03; Alkalinity: 400 ppmCaC03; Total dissolved solids: 500 ppm; Color: 50\%; Odor: Unobjectionable; and Taste: Unobjectionable. The DOST Analytical Testing Laboratory technicians got water samples from the eight water tanks four times a year simultaneously with the microbiological test and the table shows that in terms of $\mathrm{pH}$, all of the actual values are within the range of the PNSDW standards. For the Total hardness, Calcium hardness, and alkalinity, all of the water samples were below the PNSDW standards which means they met the standards. The actual values of all the water samples from the eight water tanks in terms of Total dissolved solids exceeded the PNSDW standards which mean it is not within the standards. In terms of color, all of the water samples from the eight water tanks have actual values of less than $50 \%$ which means within the standards of 50\% in the PNSDW standards. Water samples from water tank number 3 have objectionable results instead of unobjectionable for odor and taste which is indicated in the PNSDW standards which means not within the standards. 
Table 4 Physico Chemical Properties Test Results of Water from the Water Tanks of the HEI for 2019

\begin{tabular}{|c|c|c|c|c|c|c|c|c|}
\hline Parameters & Tank 1 & Tank 2 & Tank 3 & Tank 4 & Tank 5 & Tank 6 & Tank 7 & Tank 8 \\
\hline \multirow{4}{*}{$\mathrm{pH}$} & 7.8 & 8 & 7.9 & 7.9 & 7.9 & 7.9 & 7.8 & 7.9 \\
\hline & 7.8 & 8.2 & 7.9 & 8 & 7.9 & 8 & 7.9 & 7.8 \\
\hline & 7.7 & 8.1 & 7.9 & 7.5 & 7.7 & 7.4 & 7.8 & 7.5 \\
\hline & 7.4 & 7.5 & 7.4 & 7.4 & 7.7 & 7.6 & 7.6 & 7.5 \\
\hline \multirow{4}{*}{$\begin{array}{c}\text { Total } \\
\text { Hardness }\end{array}$} & $35 \mathrm{ppm}$ & 56ppm CaCO3 & 35ppm CaCO3 & 35ppm CaCO3 & 56ppm CaCO3 & 105ppm CaCO3 & 147ppm CaCO3 & 56ppm CaCO3 \\
\hline & $35 \mathrm{ppm} \mathrm{CaCO}{ }_{3}$ & $56 \mathrm{ppm} \mathrm{CaCO}_{3}$ & $28 \mathrm{ppm} \mathrm{CaCO}_{3}$ & $28 \mathrm{ppm} \mathrm{CaCO}_{3}$ & $63 \mathrm{ppm} \mathrm{CaCO}_{3}$ & $49 \mathrm{ppm} \mathrm{CaCO}_{3}$ & $147 \mathrm{ppm} \mathrm{CaCO}_{3}$ & $49 \mathrm{ppm} \mathrm{CaCO}_{3}$ \\
\hline & $42 \mathrm{ppm} \mathrm{CaCO}_{3}$ & $56 \mathrm{ppm} \mathrm{CaCO}_{3}$ & $35 \mathrm{ppm} \mathrm{CaCO}_{3}$ & $28 \mathrm{ppm} \mathrm{CaCO} 3$ & $56 \mathrm{ppm} \mathrm{CaCO}_{3}$ & 98ppm $\mathrm{CaCO}_{3}$ & $147 \mathrm{ppm} \mathrm{CaCO}_{3}$ & $56 \mathrm{ppm} \mathrm{CaCO}_{3}$ \\
\hline & $49 \mathrm{ppm} \mathrm{CaCO}_{3}$ & $49 \mathrm{ppm} \mathrm{CaCO}_{3}$ & $28 p p m \mathrm{CaCO}_{3}$ & $28 p p m \mathrm{CaCO}_{3}$ & $56 \mathrm{ppm} \mathrm{CaCO}_{3}$ & $56 \mathrm{ppm} \mathrm{CaCO}_{3}$ & $147 \mathrm{ppm} \mathrm{CaCO}_{3}$ & $49 \mathrm{ppm} \mathrm{CaCO}_{3}$ \\
\hline \multirow{4}{*}{$\begin{array}{l}\text { Calcium } \\
\text { Hardness }\end{array}$} & $27 \mathrm{ppm} \mathrm{CaCO}_{3}$ & $43 \mathrm{ppm} \mathrm{CaCO}_{3}$ & $27 \mathrm{ppm} \mathrm{CaCO}_{3}$ & $27 \mathrm{ppm} \mathrm{CaCO}_{3}$ & $43 \mathrm{ppm} \mathrm{CaCO}_{3}$ & $80 \mathrm{ppm} \mathrm{CaCO}_{3}$ & $112 \mathrm{ppm} \mathrm{CaCO}_{3}$ & $43 \mathrm{ppm} \mathrm{CaCO}_{3}$ \\
\hline & $27 \mathrm{ppm} \mathrm{CaCO}_{3}$ & $43 \mathrm{ppm} \mathrm{CaCO}_{3}$ & $21 \mathrm{ppm} \mathrm{CaCO}_{3}$ & $21 \mathrm{ppm} \mathrm{CaCO}_{3}$ & 48ppm $\mathrm{CaCO}_{3}$ & $37 \mathrm{ppm} \mathrm{CaCO} 3$ & $112 \mathrm{ppm} \mathrm{CaCO}_{3}$ & $37 \mathrm{ppm} \mathrm{CaCO}_{3}$ \\
\hline & $32 \mathrm{ppm} \mathrm{CaCO}_{3}$ & $43 \mathrm{ppm} \mathrm{CaCO}_{3}$ & $27 \mathrm{ppm} \mathrm{CaCO}_{3}$ & $21 \mathrm{ppm} \mathrm{CaCO}_{3}$ & $63 \mathrm{ppm} \mathrm{CaCO}_{3}$ & $74 \mathrm{ppm} \mathrm{CaCO}_{3}$ & $112 \mathrm{ppm} \mathrm{CaCO}_{3}$ & $43 \mathrm{ppm} \mathrm{CaCO} 3$ \\
\hline & $37 \mathrm{ppm} \mathrm{CaCO}_{3}$ & $37 \mathrm{ppm} \mathrm{CaCO}_{3}$ & $21 \mathrm{ppm} \mathrm{CaCO}_{3}$ & $21 \mathrm{ppm} \mathrm{CaCO}_{3}$ & $43 \mathrm{ppm} \mathrm{CaCO}_{3}$ & $43 \mathrm{ppm} \mathrm{CaCO}_{3}$ & $112 \mathrm{ppm} \mathrm{CaCO}_{3}$ & $37 \mathrm{ppm} \mathrm{CaCO}_{3}$ \\
\hline \multirow{4}{*}{ Alkalinity } & $280 \mathrm{ppm} \mathrm{CaCO}_{3}$ & $300 \mathrm{ppm} \mathrm{CaCO}_{3}$ & $320 \mathrm{ppm} \mathrm{CaCO}_{3}$ & $300 \mathrm{ppm} \mathrm{CaCO}_{3}$ & $340 \mathrm{ppm} \mathrm{CaCO}_{3}$ & $340 \mathrm{ppm} \mathrm{CaCO}_{3}$ & $360 \mathrm{ppm} \mathrm{CaCO}_{3}$ & $340 \mathrm{ppm} \mathrm{CaCO}_{3}$ \\
\hline & $280 \mathrm{ppm} \mathrm{CaCO}_{3}$ & $340 \mathrm{ppm} \mathrm{CaCO}_{3}$ & $300 \mathrm{ppm} \mathrm{CaCO}_{3}$ & $300 \mathrm{ppm} \mathrm{CaCO}_{3}$ & $320 \mathrm{ppm} \mathrm{CaCO}_{3}$ & $340 \mathrm{ppm} \mathrm{CaCO}_{3}$ & $380 \mathrm{ppm} \mathrm{CaCO}_{3}$ & $360 \mathrm{ppm} \mathrm{CaCO}$ \\
\hline & $260 \mathrm{ppm} \mathrm{CaCO}_{3}$ & $320 \mathrm{ppm} \mathrm{CaCO}_{3}$ & $300 \mathrm{ppm} \mathrm{CaCO}_{3}$ & $280 \mathrm{ppm} \mathrm{CaCO}_{3}$ & $340 \mathrm{ppm} \mathrm{CaCO}_{3}$ & $340 \mathrm{ppm} \mathrm{CaCO}_{3}$ & $360 \mathrm{ppm} \mathrm{CaCO}_{3}$ & $340 \mathrm{ppm} \mathrm{CaCO}_{3}$ \\
\hline & $240 \mathrm{ppm} \mathrm{CaCO}_{3}$ & $280 \mathrm{ppm} \mathrm{CaCO}_{3}$ & $260 \mathrm{ppm} \mathrm{CaCO}_{3}$ & $280 \mathrm{ppm} \mathrm{CaCO}_{3}$ & $320 \mathrm{ppm} \mathrm{CaCO}_{3}$ & $300 \mathrm{ppm} \mathrm{CaCO}_{3}$ & $320 \mathrm{ppm} \mathrm{CaCO}_{3}$ & $340 \mathrm{ppm} \mathrm{CaCO}_{3}$ \\
\hline \multirow{4}{*}{$\begin{array}{l}\text { Total } \\
\text { Dissolved } \\
\text { Solids }\end{array}$} & $1221 \mathrm{ppm}$ & 720ppm & $1260 \mathrm{ppm}$ & $1244 \mathrm{ppm}$ & 767ppm & $1100 \mathrm{ppm}$ & $1157 \mathrm{ppm}$ & 737ppm \\
\hline & 1112ppm & $705 \mathrm{ppm}$ & 1158ppm & $1126 \mathrm{ppm}$ & 771ppm & $1137 \mathrm{ppm}$ & $1186 p p m$ & $907 \mathrm{ppm}$ \\
\hline & 1098ppm & $690 \mathrm{ppm}$ & $1206 p p m$ & $1225 \mathrm{ppm}$ & 757ppm & $1089 \mathrm{ppm}$ & 1148ppm & $855 p p m$ \\
\hline & $1146 \mathrm{ppm}$ & 1173ppm & $1166 \mathrm{ppm}$ & $1080 \mathrm{ppm}$ & 753ppm & 761ppm & $1212 \mathrm{ppm}$ & 827ppm \\
\hline \multirow{2}{*}{ Color } & less than $50 \%$ & less than $50 \%$ & less than $50 \%$ & less than $50 \%$ & less than $50 \%$ & less than $50 \%$ & less than $50 \%$ & less than $50 \%$ \\
\hline & less than $50 \%$ & less than $50 \%$ & less than $50 \%$ & less than $50 \%$ & less than $50 \%$ & less than $50 \%$ & less than $50 \%$ & less than $50 \%$ \\
\hline
\end{tabular}


Global Journal of Engineering and Technology Advances, 2021, 08(01), 072-083

\begin{tabular}{|c|c|c|c|c|c|c|c|c|}
\hline & less than $50 \%$ & less than $50 \%$ & less than $50 \%$ & less than $50 \%$ & less than $50 \%$ & less than $50 \%$ & less than $50 \%$ & less than $50 \%$ \\
\hline & less than $50 \%$ & less than $50 \%$ & less than $50 \%$ & less than $50 \%$ & less than $50 \%$ & less than $50 \%$ & less than $50 \%$ & less than $50 \%$ \\
\hline \multirow{4}{*}{ Odor } & Unobjectionable & Unobjectionable & Objectionable & Unobjectionable & Unobjectionable & Unobjectionable & Unobjectionable & Unobjectionable \\
\hline & Unobjectionable & Unobjectionable & Objectionable & Unobjectionable & Unobjectionable & Unobjectionable & Unobjectionable & Unobjectionable \\
\hline & Unobjectionable & Unobjectionable & Objectionable & Unobjectionable & Unobjectionable & Unobjectionable & Unobjectionable & Unobjectionable \\
\hline & Unobjectionable & Unobjectionable & Unobjectionable & Unobjectionable & Unobjectionable & Unobjectionable & Unobjectionable & Unobjectionable \\
\hline \multirow{4}{*}{ Taste } & Unobjectionable & Unobjectionable & Objectionable & Unobjectionable & Unobjectionable & Unobjectionable & Unobjectionable & Unobjectionable \\
\hline & Unobjectionable & Unobjectionable & Objectionable & Unobjectionable & Unobjectionable & Unobjectionable & Unobjectionable & Unobjectionable \\
\hline & Unobjectionable & Unobjectionable & Objectionable & Unobjectionable & Unobjectionable & Unobjectionable & Unobjectionable & Unobjectionable \\
\hline & Unobjectionable & Unobjectionable & Unobjectionable & Unobjectionable & Unobjectionable & Unobjectionable & Unobjectionable & Unobjectionable \\
\hline
\end{tabular}




\subsection{Groundwater Economic value}

The first aspect included in the determination of the economic value of groundwater is the cost of pipes, motors, pumps, and water supply fixtures used in the extraction and distribution of groundwater. From all the buildings existing and being used by the faculty members, non-teaching personnel, and students of the HEI, in the computation as provided by the professional in-charge for the plumbing planning, design, and bill of quantities; its plumbing item cost is equal to 6.57 percent of the total cost of the building. The cost of buildings is ranging from 2 million pesos to 100 million pesos which were constructed way back forty years ago until 2014 from one-storey ( 3 units) to five-storey buildings, where most of the buildings are three to five-storey level. In terms of pipes, motors, and pumps like those used in the elevated tower water tanks the plans, designs, and bill of quantities have separated project costs, which range from 900,000 pesos to more than a million pesos, likewise the deep wells and shallow wells with its motors and pumps.

The second aspect is the electricity cost of extracting groundwater up to its distribution to the water supply fixtures. The water being used by the faculty members, non-teaching personnel, and students are not provided by the Local Water District but instead, the HEI drilled deep wells and shallow wells to provide groundwater supply to the stakeholders. The HEI is paying 3 million pesos to 4 million pesos for the electricity bill every month due to the operational activities which utilize equipment, air conditioning units, and others occurring in all the buildings including the extraction and distribution of groundwater. The average monthly electricity bill paid for the groundwater extraction is ranging from one-half million pesos or more every month.

\subsection{Problems encountered on groundwater utilization in the HEI}

The researchers conducted interviews with the stakeholders of the HEI. Here are their responses about the problems they have encountered in using the water supplied through the water supply fixtures.

\subsubsection{Faculty $A$}

The usual problem encountered by faculty members in terms of water supply in our building are the following: low pressure of water on faucets and water closets and there are times that there is no water supply in faucets and water closets. Our building has been existing for more than twenty years now, probably there are pipes embedded in the concrete which corroded already and with small holes that cause leaking. There are newly installed and exposed pipes for the water supply of bidets. I've observed that the water from the flush tank of the water closet is continuously flowing, the fittings should be checked to conserve water and minimize the cost of electricity bills.

\subsubsection{Faculty $B$}

Water from the bidet has a foul odor. The storage water tank has to be cleaned including the pipelines, there may be bacteria present in it and therefore it is unsafe to use the water. There are tower elevated water tanks that supply water in most buildings of the HEI and there are deep wells and shallow wells where groundwater is extracted. The HEI is not connected to the City Water District, so the groundwater is extracted and distributed with the use of electric pumps and submersible pumps for the consumption of HEI stakeholders.

\subsubsection{Faculty $C$}

The groundwater extracted and distributed to the different buildings is used for cleaning purposes and laboratory experiments. The faculty members, non-teaching personnel, and students are drinking water from the water dispenser bought from the Refilling Stations/ water provider, all of the stakeholders brought drinking tumblers. There are times that the color of groundwater from the faucet is light brown.

\subsubsection{Student $A$}

I am wondering why the occupants of our building are very near to the elevated water tank, yet we experienced low pressure of water in the faucets and water closets especially on the fourth-floor level. Usually in the morning, when we open the faucet in our laboratory sink, the water has a foul odor and not purely colorless. When we have to perform a cooking and baking laboratory, we were required to use mineral water bought in the refilling station.

\subsubsection{Student B}

There is no water in the urinals and faucets, there is a big drum where the water is stored in the comfort room. In the laboratory, although there is a connection of the faucets in the installed pipelines, still it is not working. I have not seen 
a student taking water from the faucet and drink it. The Local student council in our building provides a water dispenser and gallons of water for the consumption of students bought and delivered by a water refilling provider.

\subsubsection{Student $C$}

In our building, the water supply is always at low pressure, there are cubicles with a water closet and bidet but sad to note, it's not functional due to lack of water supply. When my classes are on the fourth floor and I have to use the comfort room, I still have to go to the first floor or sometimes control going there because it will take time, sometimes I thought I may have sickness controlling to release my urine.

\subsubsection{Non-Teaching Personnel A}

I've been working in the University for four years as a staff in one of the Administrators in the Administration building, these are my observations about the water supply in that building: the foul odor of water coming out of the faucet and bidet; after the lunch break, I have to brush my teeth, before I used the water from the faucet but this time, I am using the water from the water dispenser, am afraid the water has bacteria that may cause sickness to me.

\subsubsection{Non-Teaching Personnel B}

My work in the University is to assist the plumber, the buildings have sufficient plumbing fixtures and water supply equipment and fixtures that were constructed inclusive of the building completion, since there are twenty buildings in the HEI, two teams of plumbers were created to maintain it. There are tower elevated water tanks aside from the tanks installed on the highest floor with water pumps. If the building is three floors or more water storage tanks are installed on the rooftop and with two or one floor depend on the pressurized water tank on the ground floor. With the number of faculty members, non-teaching personnel, and students using these comfort room facilities, even the maintenance personnel find it difficult to respond on time. The HEI is like one barangay with many people living there. The water consumed daily is equivalent to the needs of a community.

\subsubsection{Non-Teaching Personnel C}

I am assigned to housekeeping of the hostel/ dormitory. There are two buildings used as hostel/ dormitory inside the HEI campus. The usual occupants of the hostel/ dormitory are international students, local and international faculty members, athletes, and other guests of the HEI. The international students usually stayed in the HEI hostel/dormitory during winter and summertime in their country (December to February and June to August). The water consumption in this period is too much as it can be checked in the electric meter installed per floor.

\subsubsection{Professional A}

I've been working in the university's Project Management Office for about four and a half (4.5) years now. I am assigned as a site engineer and plumbing designer for low-rise buildings construction and room renovations. One of my observations regarding the water supply is that too many buildings are connected to the main source (water supply from groundwater), which may be one of the reasons why there is an "inadequate" supply of water. Secondly, not all buildings are equipped with an appropriate system to meet the demand for water pressure at each floor level. Lastly, water closets are observed to have changed in color using groundwater for flushing. Water discharged from the faucet to the lavatory had a foul odor as well.

\subsection{Proposed Groundwater Sustainability Initiative in the Higher Education Institution}

- The two parks may be improved through landscaping or planting fruit-bearing trees and native/indigenous trees of the province. The faculty members and students may maintain an organic garden that is unique and can be used as a demonstration project for the city and the HEI to work together and learn organic gardening using permaculture and indigenous knowledge, principles, and practices.

- Improve the maintenance and management of the water supply facilities and fixtures, to have efficient use of energy and resources not only beneficial to the environment but also is prudent in terms of the HEI's financial health. Replace pipes with leaks and corroding, and use organic materials which may remove the foul odor, making water colorless and produce potable water which ensures cleanliness and water potability.

- Include in the future planning of buildings the Green Technology for water conservation and preservation of the environment.

- Prepare instructional materials that integrate values and technologies for maintaining the water supply, community-based water management, and sanitation services as an extension service program of the college/campus with their partner Local Government Units and schools and which can promote/enhance skills development among plumbers or water technicians. 
- Develop materials to facilitate information exchanges in Basic Education schools by promoting and participating in quality education extension programs through increasing the awareness about the impacts of water-related issues and responsible behavior in the water resources and its utilization among teachers and administrators.

- Develop a software/program for a specific building (ICT-based building) that can be used by the Facilities Maintenance and Management Office in monitoring the issues and problems of water supply in that particular building, initially, prepare a Preventive and Management Plan of the building.

- Conduct water quality and quantity audits in all buildings and its groundwater sources.

- Celebrate World Water Day, every March 22nd yearly, to increase awareness of the HEI's stakeholders on the importance and access to freshwater and explore possibilities to ensure sustainable clean water and sanitation. Yearly, the Institute of Environmental Governance may host the event and organize activities like presentations of new technologies and innovations on water conservation, qualities and learn more about other water-related issues that can be participated by faculty members and students of the HEI.

- Develop a Master Plan to avoid Water Sources Scarcity, initially with the city and later with all the cities and municipalities of the province. The ground and surface are two major sources of water, consider the El Niño and La Niña phenomena.

- Institutionalize a Water security policy in the HEI through protection and conservation of groundwater.

\section{Conclusion}

The following conclusions were drawn from the findings of the study:

- $\quad$ There are too many deep wells and shallow wells used to extract groundwater in the HEI campus.

The capacity in gallons of the elevated tower water tanks is enough to supply water in all the buildings of the HEI.

Every building in the HEI is well planned and designed in terms of water supply fixtures required. The population of the HEI requires too much demand for water supply.

The existing water supply fixtures and population of the HEI required a big volume of extracted groundwater.

- The water quality of the groundwater in the HEI in terms of microbiological and physicochemical properties test results have no indications that these may be valid for a prolonged period of time.

- The cost or value of money is directly proportional to the water supply fixtures, pipes, motors, and payment for the electricity bill to extract groundwater and provide water supply to the stakeholders of the HEI.

- There are corresponding solutions for every problem encountered by the stakeholders interviewed and included in the proposed Water Sustainable Management Plan.

\section{Compliance with ethical standards}

\section{Acknowledgments}

We would like to express our special thanks of gratitude to those who participated in this study, to the utility workers, plumbers, pipefitters, maintenance, my staff, workers, faculty members, non-teaching personnel, and students who were involved in the data gathering, especially in answering the checklist/questionnaire and in the conduct of interviews. Any attempt at any level can't be satisfactorily completed without their help and support.

\section{Disclosure of conflict of interest}

My co-author, Dr. Audie L. Geronimo, declares that he has NO conflict of interest. We have an agreement as husband and wife researchers that I am the team leader and he's the collaborator.

\section{References}

[1] Anderson, Cauchi, Mozina, and Smyth. Approaches to Achieve Sustainable Use and Management of Groundwater Resources in the Murray-Darling Basin Using Rules and Resource Condition Limits Literature Review Report. 2014; 40-41.

[2] Babcock, Matthew et.al. Improving Small Water System Projects Resources and Recommendations for Safe Water Network, II. Groundwater Depletion Mitigation-Case Study Recommendations. 2013; 27-28. 
[3] Fajardo, Max B. Plumbing Design and Estimate, Second edition. 1994.

[4] Kaur, Tajinder, Bhardwaj, Renu, Arora, Saroj. Assessment of groundwater quality for drinking and irrigation purposes using hydrochemical studies in Malwa region, southwestern part of Punjab, India. 2017; 1-2.

[5] Mitra, Sucharita. Groundwater Sustainability - A Brief Review. 2015; 1

[6] Mostafa, Amr, Al-Wasify, Raed, Sayed, Amr and Haroun, Bakry. Microbiological and Physicochemical Evaluation of Groundwater in Egypt. 2013; 2.

[7] Pradhanang, Soni, Shrestha, Suresh Das, Steenhuis, Tammo. A Review of Groundwater status, challenges, and research needs in the Kathmandu Valley, Nepal. 2012; 2.

[8] Sujay, Raghavendra N, Paresh, Chandra Deka. Sustainable Development and Management of Groundwater Resources in Mining Affected Areas: A Review. 2015; 603.

[9] Gregor, Miloš. Surface and Groundwater Quality Changes in Periods of the Water Scarcity. 2012; 16. 